\title{
Three Dimensional Structural Modelling of Lipase Encoding Gene from Soil Bacterium Alcaligenes sp. JG3 Using Automated Protein Homology Analysis
}

\author{
Dilin Rahayu Nataningtyas, Tri Joko Raharjo*, and Endang Astuti \\ Department of Chemistry, Faculty of Mathematics and Natural Sciences, Universitas Gadjah Mada, \\ Sekip Utara BLS 21, Bulaksumur, Yogyakarta 55281, Indonesia
}

* Corresponding author:

email:trijr_mipa@ugm.ac.id

Received: March 21, 2018

Accepted: October 14, 2018

DOI: $10.22146 / \mathrm{ijc} .34152$

\begin{abstract}
Bacterial lipases have significant potential to be used as the biocatalyst for many chemical reactions. In this study, a novel gene encoding lipase was isolated from an Alcaligenes sp. JG3. A pair of designed primer has successfully isolated $1 \mathrm{~kb}$ (LipJG3) that shares $98 \%$ identity towards lipase from Alcaligenes faecalis during sequence analysis. By using in silico tools, LipJG3 was related to the transporter protein sequences. Three highly conserved regions consisting of EASGSKT, VILLD, and LSGGQQQRVAIA were found. These regions were known as ATP-binding signature at Walker-A and Walker-B motifs and the $S$ signature of $A B C$ transporter family respectively. In addition, the 3-D structure of LipJG3 has been suggested but the role of the catalytic triad residues have been not fully understood.
\end{abstract}

Keywords: alcaligenes; lipase gene; LipJG3; ABC transporter protein

\section{- INTRODUCTION}

Lipases (EC 3.1.1.3) are a group of hydrolase enzymes that break down the carboxyl ester bonds of triacylglycerols to fatty acids and glycerol under waterlipid interface. The hydrolytic property of lipases allows them to be used in several chemical reactions, including transesterification, acylation, alcoholysis, and resolution of racemates [1-2]. As a biocatalyst, the boundless industrial applications of lipases are apparent in beverages, food dressing, dairy, pharmaceuticals, cosmetics, paper and leather productions [3].

In general, the genes encoding lipase enzyme are highly variable in the length and homology of encoding sequences. Nevertheless, they share the similar signature motif of a pentapeptide region, Gly-X-Ser-X-Gly, the three-dimensional structural fold, $\alpha / \beta$-hydrolase fold, and machinery catalytic residues, Ser, His, Asp or Glu [4]. The serine residue is usually located as a part of GXSXG region between the fifth $\beta$ strand and the following $\alpha$ helix,

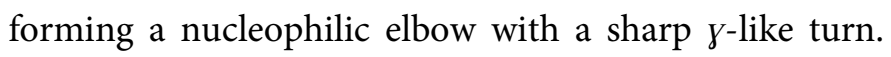
However, the location of the other catalytic residues in the protein fold seems to vary [5].

Microbial lipases are further advantageous and more stable than lipases delivered from animals and plants. Furthermore, microbial lipases have the high yield potential, diverse properties available and ease of genetic manipulation [6-7]. Therefore, new exploration of microbial lipase is indispensable. In previous studies, an extracellular lipase from bacterial strain JG3 revealed an activity to catalyze the hydrolysis of triacylglycerol from olive oil [8]. However, the taxonomy status of this bacterium is not clear. The fragment of the lipase gene $(0.4 \mathrm{~kb})$ was amplified using degenerate PCR technique, resulting in a $98 \%$ similarity towards a lipase gene from A. faecalis [9]. Accordingly, this strain JG3 is considered as a member of Alcaligenes genus.

In this present investigation, we report the sequence analysis and characterization of the lipase gene from bacterial strain JG3 (LipJG3). The enzyme is expected to be successfully sequenced prior to gene cloning and genetic manipulation, possibly useful for catalyzing biodiesel production and biochemical reactions.

\section{- EXPERIMENTAL SECTION}

\section{Materials}

The lipase producing bacterium strain JG3 collected from Purwokerto area, Central Java, was used 
as the genomic DNA source. The PCR primers used in this study were synthesized at IDT DNA, Singapore. All analytical and molecular biology grade of chemicals used in this study were commercially available; Nutrient Agar (NA) and Nutrient Broth (NB) (Sigma Aldrich), DNA ladder (Vivantis), Go Taq Green (Promega), nuclease-free water (NFW) (Gibco), ExoSAP IT kit (USB), PureLinkTM Quick Gel Extraction kit (Life Technologies), and BigDye X-terminator Kit (Applied Biosystem).

\section{Instrumentation}

The instruments used in this study were the vortex machine (Thermolyne, UK), bio centrifuge (Sorvall, UK), UV-Vis Spectrophotometer (Shimadzu, Japan), Thermal Cycler (Bio Rad), Gel Electrophoresis (Bio Rad), UV transiluminaor (Bio Rad), and DNA Sequencer (Applied Biosystem 3500 Genetic Analyzer), MEGA 7.0 software, and bioinformatics online servers.

\section{Procedure}

\section{Bacterial identification based on 16S rRNA sequence}

A single colony of bacterial culture from the solid NA medium was taken and mixed well with $50 \mu \mathrm{L}$ NFW. The mixture was incubated at $96^{\circ} \mathrm{C}$ for $10 \mathrm{~min}$ and then centrifuged at 12,500 rpm for $3 \mathrm{~min}$. The amplification of $16 \mathrm{~S}$ rRNA gene was conducted as previously described by a previous study [10]. The universal primers used were 27F (AGAGTTTGATCMTG GCTCAG) and 1642R (CGGYTACCTTGTTACGAC). The $25 \mu \mathrm{L}$ PCR mix contained $12.5 \mu \mathrm{L}$ Go Taq Green, $1 \mu \mathrm{L}$ bacterial DNA, 10 pmol $(1 \mu \mathrm{L})$ primers, and $9.5 \mu \mathrm{L}$ NFW. The condition for thermal cycling were as follows: initial denaturation at $95{ }^{\circ} \mathrm{C}$ for $4 \mathrm{~min}$, followed by 30 cycles, including denaturation step at $95{ }^{\circ} \mathrm{C}$ for $50 \mathrm{sec}$, annealing step at $55{ }^{\circ} \mathrm{C}$ for $50 \mathrm{sec}$, elongation step at $72{ }^{\circ} \mathrm{C}$ for $2 \mathrm{~min}$, and one last cycle of final elongation at $72{ }^{\circ} \mathrm{C}$ for $7 \mathrm{~min}$. A single DNA fragment observed on the electrophoresis gel agarose was purified by ExoSAP IT kit prior to DNA sequencing. A cladogram with neighbor-joining algorithm was built up using MEGA 7.0 software [11].

\section{Isolation of lipase gene}

Prior to lipase gene amplification, the bacterial cells were harvested by centrifugation at $12,500 \mathrm{rpm}$ and washed with PBS (phosphate buffer saline) solution. A modified method according to a preceding study [12] was employed to isolate genomic DNA from bacterial strain JG3. Fifty ng of isolated DNA was taken as the template for PCR amplification. The lipase gene was amplified using primers, DF1 (ATGACCGAGCTGACT GTAG) and DR1 (AGGAGGGGTAAATCCACAG). The PCR conditions used were initial denaturation at $95{ }^{\circ} \mathrm{C}$ for $5 \mathrm{~min}$, followed by 35 cycles, including denaturation step at $95{ }^{\circ} \mathrm{C}$ for $1 \mathrm{~min}$, annealing step at $57^{\circ} \mathrm{C}$ for $30 \mathrm{sec}$, elongation step at $72^{\circ} \mathrm{C}$ for $1 \mathrm{~min}$, along with one last cycle of final elongation at $72^{\circ} \mathrm{C}$ for $5 \mathrm{~min}$. The amplified gene was examined on $1.5 \%$ agarose gel, then extracted and purified by PureLinkTM Quick Gel Extraction kit.

\section{DNA sequencing and sequence analysis}

The lipase gene was sequenced using the aformentioned primers using an Applied Biosystem 3500 Genetic Analyzer and BigDye X-terminator Kit. Consecutively, the sequence was analyzed using BLAST program (https://blast.ncbi.nlm.nih.gov/Blast.cgi) and compared with other sequences in the GenBank, before translation into an amino acid sequence using the ExPAsy tool (http://web.expasy.org/translate/) to predict the possible open reading frame (ORF). The similar lipase sequences from the same bacterial genus of the JG3 bacterial sample retrieved from GenBank database were aligned using ClustalW.

\section{Computer-aided modelling of 3D structure of LipJG3}

To identify the conserved regions in the LipJG3 sequence, homology analysis using ConSeq server (http://consurf.tau.ac.il/) was carried out. The aligned homologous sequence were retrieved from UNIREF90 database. The MSA (Multiple Sequence Alignment) using MAFFT available in the server was performed by employing default parameter with Bayesian method to calculate the Conservative scores. Moreover, the secondary 

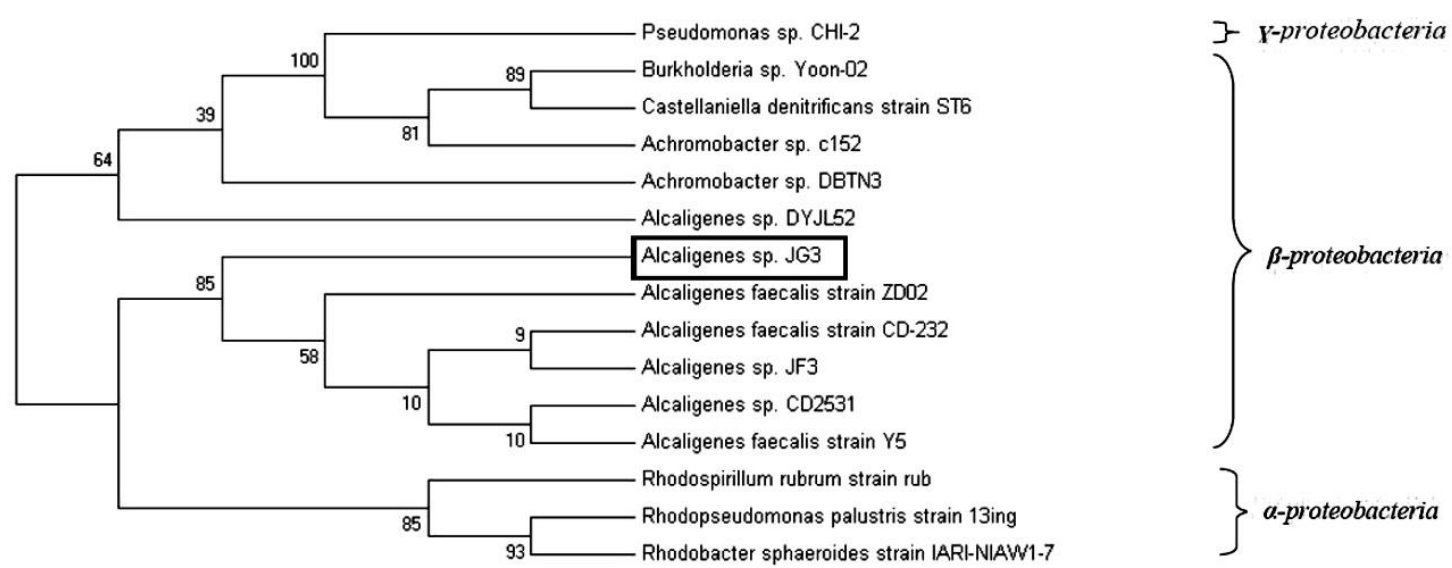

Fig 1. Position of Alcaligenes sp. JG3 based on $16 \mathrm{~S}$ rRNA gene sequence relative to other proteobacteria in a cladogram generated by MEGA 7.0. Numbers at nodes indicate bootstrap values expressed as a percentage of 1,000 replicates

and tertiary structures of LipJG3 were aligned using SWISS-MODEL [13] and Phyre2 server (http://www.sbg.bio.ic.ac.uk/Phyre2) [14]. The chosen 3D model was analyzed and validated using MolProbity (http://molprobity.biochem.duke.edu/) [15]. The results were visualized using the UCSF Chimera version 1.11 .2 [16].

\section{- RESULTS AND DISCUSSION}

Currently, knowledge on lipases produced by genus Alcaligenes is very limited, obtained mainly from bacterial samples isolated from tropical area in Indonesia. The strain used in this study showed a considerable lipolytic activity [8] and is possibly a good source of new bacterial lipase [17]. On the other hand, recombinant technology through DNA cloning has led to far-reaching applications in industries, agriculture and environmental activities [18]. Hence, the characterization of DNA encoding lipase from strain JG3 is our point of interest. The present study reports the molecular characterization of Alcaligenes sp. JG3 lipase including its predicted 3D structure.

\section{Identification of Lipase-Producing Bacteria}

Strain JG3 is a gram-negative bacterium with a size of $0.7-1.0 \times 0.5-2.6 \mu \mathrm{m}$ of rod or coccobacilli shape [19]. In this study, about 1500 bp of $16 \mathrm{~S}$ rRNA gene of strain JG3 has been successfully amplified to identify its genotypic character. BLAST results showed that strain

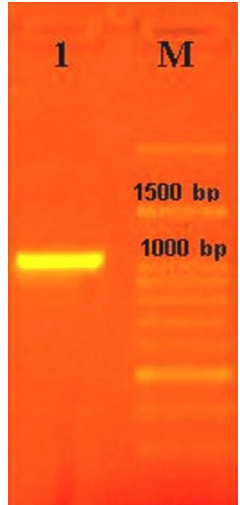

Fig 2. Gel electrophoresis analysis of PCR products using designed primers, DF1 and DR1. Lane 1, 1 kb PCR product; M: 100-bp DNA ladder (marker)

JG3 has the highest identity with Alcaligenes faecalis, corresponding to a $96 \%$ homologous significant value. This percentage (96\%) similarity showed us the strain JG3 belongs to different species of Alcaligenes genus [2021]. From the phylogenetic tree (Fig. 1.), a neighborjoining algorithm showed that strain JG3 belongs to the group of Betaproteobacteria and its ancestry is closely related to the A. faecalis species. This means that the strain JG3 is within the outer group of Alphaproteobacteria (represented by genus Rhodobacter, Rhodospirillum, and Rhodopseudomonas) and Gamma proteobacteria (genus Pseudomonas). Accordingly, the strain JG3 was successfully confirmed as Alcaligenes sp. JG3. 
Table 1. Alignment statistic between LipJG3 and lipase from A. faecalis

\begin{tabular}{|c|c|c|c|c|c|c|c|}
\hline $\begin{array}{l}\text { Score } \\
655 \text { bits }\end{array}$ & (1690) & $\begin{array}{l}\text { Expect } \\
0.0\end{array}$ & $\begin{array}{l}\text { Method } \\
\text { Compositional matrix adjust. }\end{array}$ & $\begin{array}{l}\text { Identities } \\
325 / 332(98 \%) \\
\end{array}$ & $\begin{array}{l}\text { Positives } \\
327 / 332(98 \%)\end{array}$ & & $\begin{array}{l}\text { Gaps } \\
0 / 332(0 \%)\end{array}$ \\
\hline Query & 1 & $\begin{array}{l}\text { MSLNKGEV } \\
\text { MSLNKGEV }\end{array}$ & $\begin{array}{l}\text { LEASGSGKTTLLRAVAGLEQP } \\
\text { I ASGSGKTTLLRAVAGLEQP }\end{array}$ & $\begin{array}{l}\text { SQGRIA INNDVLYDSQA } \\
\text { SQGRIA INNDVLYDSQA }\end{array}$ & $\begin{array}{l}\text { IDLPAEARNL } \\
\text { IDLPAEARNL }\end{array}$ & 60 & \\
\hline Sbjet & 24 & MSLNKGEV & LGASGSGKTTLLRAVAGLEQP & SQGRIA INNDVLYDSQA & IDLPAEARNL & 83 & \\
\hline Query & 61 & $\begin{array}{l}\text { GLVFQSYA } \\
\text { GLVFQSYA }\end{array}$ & $\begin{array}{l}\text { HMTVQENVAYPLTLRKTSKAE } \\
\text { HMTVQENVAYPLTLRKT KAE }\end{array}$ & $\begin{array}{l}\text { SRQKVDA I LDQLGLKGL } \\
\text { SRQKVDA I LDQLGLKGL }\end{array}$ & $\begin{array}{l}\text { ERYPSQLSGG } \\
\text { ERYPSQLSGG }\end{array}$ & 120 & \\
\hline Sbjet & 84 & GLVFQSYA & HMTVQENVAYPLTLRKTPKAE & SRQKVDAILDQLGLKGL & ERYPSQLSGG & 143 & \\
\hline $\begin{array}{l}\text { Query } \\
\text { Sbjet }\end{array}$ & $\begin{array}{l}121 \\
144\end{array}$ & $\begin{array}{l}\text { QQQRVAIA } \\
\text { QQQRVAIA } \\
\text { QQQRVAIA }\end{array}$ & $\begin{array}{l}\text { VYNPPVILPDEPLSNLDAKLRI } \\
\text { VYNPPVIL DEPLSNLDAKLR } \\
\text { VYNPPVILLDEPLSNLDAKLRI }\end{array}$ & $\begin{array}{l}\text { EEARVFLRELIVQMGLS } \\
\text { EEARVFLRELIVQMGLS } \\
\text { EEARVFLRELIVQMGLS }\end{array}$ & $\begin{array}{l}\text { LMVTHDQAEA } \\
\text { LMVTHDQAEA } \\
\text { LMVTHDQAEA }\end{array}$ & 180 & \\
\hline Query & 181 & $\begin{array}{l}\text { MAISDRIL } \\
\text { MAISDRIL }\end{array}$ & $\begin{array}{l}\text { GGEIGEQGSPQEVYSNPLTLY } \\
\text { GGEI +QG+PQEVYSNP TLY }\end{array}$ & $\begin{array}{l}\text { TAEFMGSNNRLQGKVTE } \\
\text { TAEFMGSNNRLQGKVTE }\end{array}$ & $\begin{array}{l}\text { RDQQIRLSGP } \\
\text { RDQQIRLSGP }\end{array}$ & 240 & \\
\hline Sbjet & 204 & MAISDRIL & GGEIEQQGTPQEVYSNPKTLY & TAE FMGSNNRLQGKVTE & RDQQIRLSGP & 263 & \\
\hline Query & 241 & $\begin{array}{l}\text { GWELWGHA } \\
\text { GWELWGHA }\end{array}$ & $\begin{array}{l}\text { LNAGQQATAVIRVEQVQLNAQ } \\
\text { LNAGQQATAVIRVEQVQLNAQ }\end{array}$ & $\begin{array}{l}\text { PGPDTLQLQLSTSMYLG } \\
\text { PGPDTLQLQLSTSMYLG }\end{array}$ & $\begin{array}{l}\text { KWEHVFRMAD } \\
\text { KWEHVFRMAD }\end{array}$ & 300 & \\
\hline Sbjet & 264 & GWELWGHA & LNAGQQATAVIRVEQVQLNAQ & PGPDTLQLQLSTSMYLG & KWEHVERMAD & 323 & \\
\hline $\begin{array}{l}\text { Query } \\
\text { Sbjet }\end{array}$ & $\begin{array}{l}301 \\
324\end{array}$ & $\begin{array}{l}\text { PSAGTLRA } \\
\text { PSAGTLRA } \\
\text { PSAGTLRA }\end{array}$ & $\begin{array}{l}\text { EPLPSGVHHLQLPPSKLWIYP } \\
\text { EPLPSGVHHLQLPPSKLWIYP } \\
\text { EPLPSGVHHLQLPPSKLWIYP }\end{array}$ & 332 & & & \\
\hline
\end{tabular}

\section{PCR Amplification of Lipase Gene}

The DF1 and DR1 primer pair designed according to the reference sequence, lipase DNA sequence of $A$. faecalis subsp. faecalis NCIB 8687 (WP_003801168.1) successfully amplified a single, $1 \mathrm{~kb}$ fragment (Fig. 2.) of the genomic DNA of Alcaligenes sp. JG3. The purified amplified DNA was sent for sequencing. Based on BLASTn analysis, new gene sequence named as LipJG3 (KY750692), showed 91\% identity with A. faecalis strain ZD02. The sequence, however, was also $73-75 \%$ similar to a lipase from the genus Enterobacter. During ClustalW alignment, LipJG3 showed high identity towards the Alcaligenes lipases deposited in GenBank, especially the $A$. faecalis MOR02 with a $96 \%$ similarity. Whereas, LipJG3 shared $\sim 87 \%$ identity with the reference sequence.

\section{The Deduced Amino Acid Sequence}

The $1 \mathrm{~kb}$ amplified LipJG3 gene corresponded to 333 amino acid (aa) of the mature sequence. The output of BLASTp program showed significant identity both biologically and statistically to lipases of A. faecalis (98\%) with the query cover and E- value of $99 \%$ and zero, respectively (Table 1). For others, it was similar to lipase from Kerstersia aviorum by $71 \%$, Achromobacter genus by $70 \%$, while with Buttiauxella and Cedecea genus shared $69 \%$ similarity. This lipase sequence showed high similarity within lipases from Alcaligenes genus. However, it is showing varying percentages among the sequences mainly at the nucleotide level, although their amino acid sequences are quite similar to each other. This signifies possible variability of codon usage in several amino acid residues, in view of the fact that a high variability among microbial lipase gene is frequently observed [22-23].

A member of certain lipase gene family is often involved in varying metabolic pathways such as for fatty acid uptake or lipid digestion. The complexity of its mechanism of action as hydrolyze enzyme in different family class still remains questions for further understanding [24]. In order to classify LipJG3, an MSA was carried out by ConSeq server [25]. The first attempt was to find the biologically important protein residues (Fig. 3). 


\section{ConSurf Results}

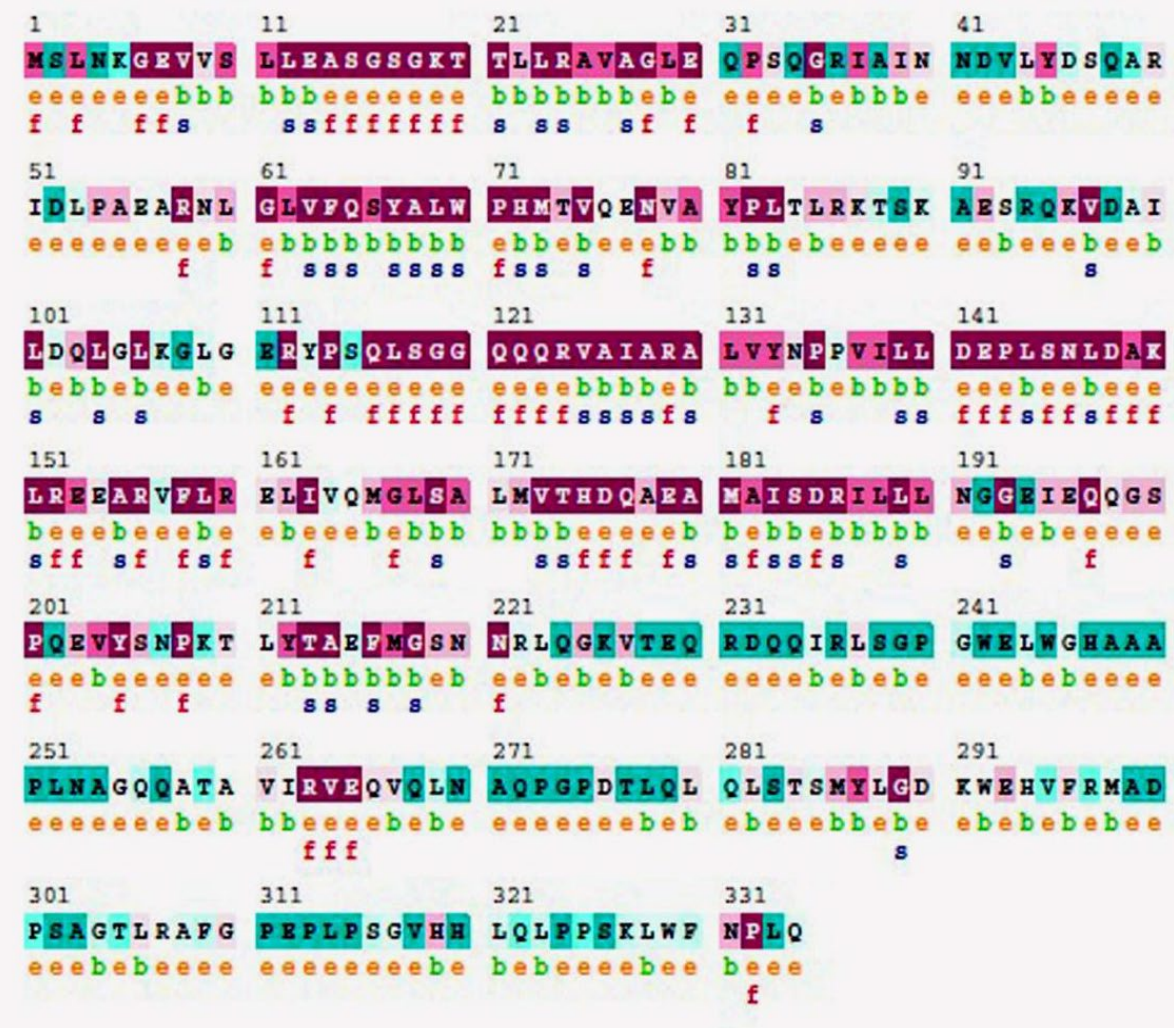

The conservation scale:

\begin{tabular}{llllllll|l|l}
1 & 2 & 3 & 4 & 5 & 6 & 7 & 8 & 9
\end{tabular}

Variable Average Conserved

e - An exposed residue according to the neural-network algorithn.

b - A buried residue according to the neural-network algor1thm.

I - A predicted runctional residue (n1ghly conserved and exposed).

s - A predicted structural res1due (n1ghly conserved and bur1ed).

Fig 3. MSA output by Conseq server

Interestingly, the GXSXG motif, a well-known conserved region should exist in every lipase gene sequence. However, it is not found in the LipJG3 sequence observed on the MSA analysis result, indicating the uniqueness of this sequence. The LipJG3 showed several distinctive conserved sequences for common lipases including EASGSGKT and QLSGGQQQRVAIARA (Fig. 3.). These two conserved regions are well-known to form a part of the transporter protein sequence. Furthermore, the MSA output described that the residues present in the protein's $\mathrm{N}$ and $\mathrm{C}$ termini were highly exposed and could be interacting with the aqueous environment to form a hydrogen bonding network that contributes to the stabilization of the three-dimensional structure [10].

The second attempt in LipJG3 homology analysis was to predict its structural model. The structure and function information on proteins are important for understanding their mechanism in the body. From the secondary structure prediction, LipJG3 contains $7 \alpha$ helices and $20 \beta$-strands (Fig. 4.) and resembles an alpha-beta $(\alpha-\beta)$ protein fold, but its folding structure is different to that of ordinary lipases. Generally, lipases contain mostly eight strands of $\beta$-sheet with the second strand sited antiparallel and the third to eighth parallel 


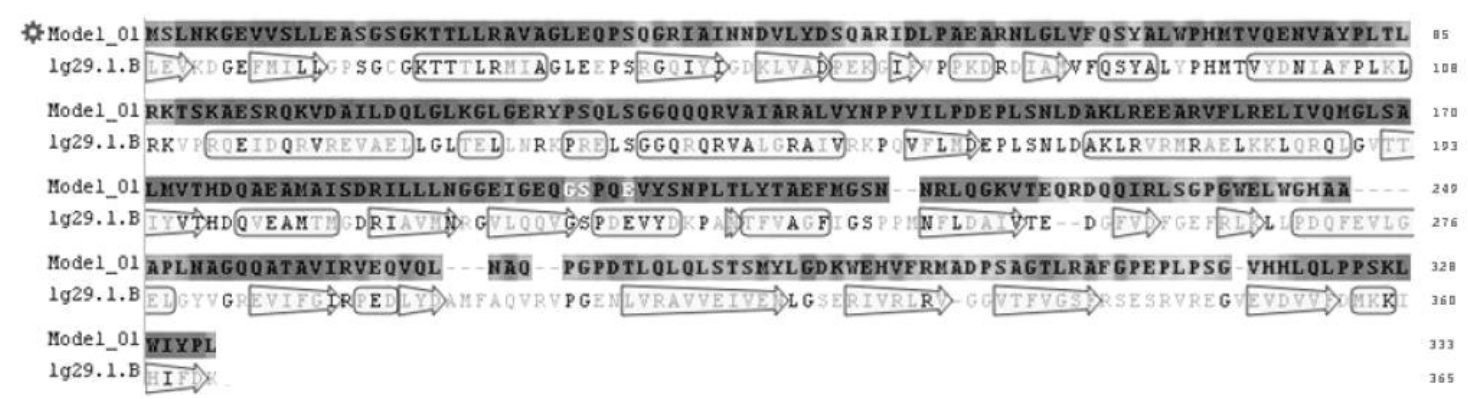

Fig 4. Secondary structure alignment between model (LipJG3) and template (PDB ID: 1g29.1) by SWISS-MODEL. Right arrow for $\beta$-strand, rounded rectangle for $\alpha$-helix structures. White characters in grey boxes (G199, S200, E203) for residues in contact with ligand $\mathrm{Mg}^{2+}$
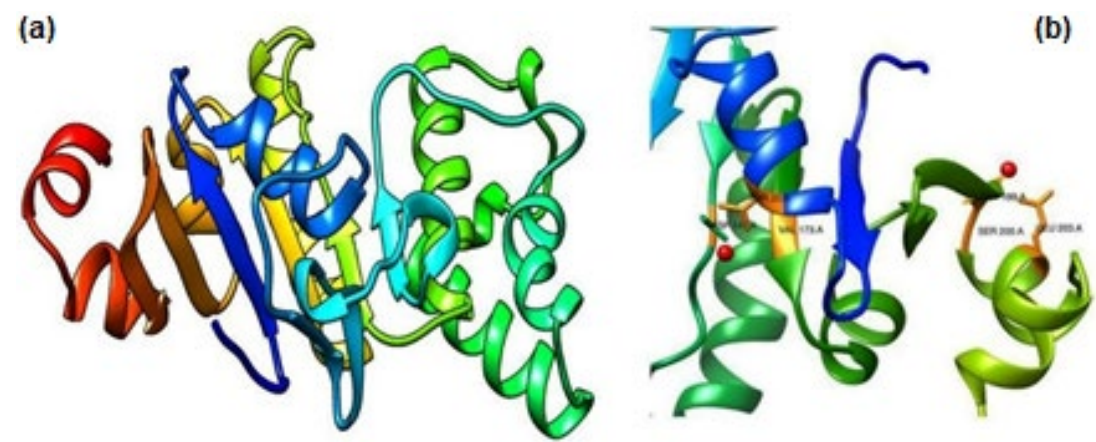

Fig 5. (a) LipJG3 3D Structure based on d1g2912 template derived from Phyre2. (b) Close-up of residues (highlighted in orange shade) from SWISS-MODEL, which interact directly with $\mathrm{Mg}^{2+}$ ions. Original model is visualized in rainbow cartoon, where blue to red color runs from the $\mathrm{N}$ to the $\mathrm{C}$ termini

$\beta$-strands are connected by $\alpha$-helices [5]. However, there are some modifications of lipase structures due to their variance in sequence length and conservation [26].

\section{LipJG3 Structural Prediction and Validation}

Apparently, LipJG3 belongs to the new lipase family or other protein classes. The highest identity of templatebased modeling by Phyre 2 was a $49 \%$ hit for the fold of Ploop containing nucleoside triphosphate hydrolase (family of ABC transporter ATPase) of Thermococcus litoralis (d1g2912) with 100\% confidence. Based on this result, the 3D structure of LipJG3 was chosen as shown in Fig. 5(a). Moreover, its validity was also analyzed using MolProbity.

Two validation processes were performed. The first was the Asn/Gln/His residue flipping correction. The result showed that correction was not needed, hence indicating that all Asn, Gln, and His residues from LipJG3 were oriented correctly. The second process involved analyses on all atom contacts and geometry. The output of this validation analysis is shown in Table 2. It showed that the structure of JG3's lipase has serious steric clashes and poor sidechain rotamers, while Ramachandran and $\mathrm{C} \beta$ deviation values were acceptable for this resolution. However, CaBLAM (Ca Based Low-Resolution Annotation Method) parameter displayed good percentage. Based on these results, the proposed 3D structure of LipJG3 is acceptable despite its low resolution, as the crystallographic structure of the similar protein, in this case, a lipase that belongs to NTPase hydrolase family, has yet to be solved.

\section{LipJG3's Important Residues}

The alignment result between LipJG3 and other lipases that belongs to the same group, it possesses similar sequence motifs, EASGSKT and LSGGQQQRV AIA as ATP- and GTP-binding site Walker-A (Fig. 6.) and an $\mathrm{ABC}$ transporter family signature respectively [27-28] as well as VILLD as ATP-binding signatures at Walker-B motif [29]. The same characteristics were also 
Table 2. MolProbity result summary and criterion chart for LipJG3 structure

\begin{tabular}{cllll}
\hline \multirow{2}{*}{ All-Atom Contacts } & Clashscore, all atoms: & \multicolumn{2}{c}{42.19} & \multicolumn{2}{l}{$7^{\text {th }}$ percentile $(\mathrm{N}=1784$, all resolutions $)$} \\
& Clashscore is the number of serious steric overlaps $(>0.4 \AA$ A $)$ per 1000 atoms. \\
\hline \multirow{5}{*}{ Protein Geometry } & Poor rotamers & 5 & $2.78 \%$ & Goal: $<0.3 \%$ \\
& Favored rotamers & 167 & $92.78 \%$ & Goal: $>98 \%$ \\
& Ramachandran outliers & 3 & $1.40 \%$ & Goal: $<0.05 \%$ \\
& Ramachandran favored & 206 & $95.81 \%$ & Goal: $>98 \%$ \\
& MolProbity score & 2.73 & & $35^{\text {th }}$ percentile $(\mathrm{N}=27675,0 \AA-99 \AA)$ \\
& C $\beta$ deviations $>0.25 \AA$ & 1 & $0.50 \%$ & Goal: 0 \\
& Bad bonds & $2 / 1692$ & $0.12 \%$ & Goal: $0 \%$ \\
& Bad angles & $38 / 2292$ & $1.66 \%$ & Goal: $<0.1 \%$ \\
\hline \multirow{2}{*}{ Peptide Omegas } & Cis Proline & $0 / 11$ & $0.00 \%$ & Expected: $\leq 1$ per chain, or $\leq 5 \%$ \\
\hline \multirow{2}{*}{ Low-resolution Criteria } & CaBLAM outliers & 2 & $0.93 \%$ & Goal: $<1.0 \%$ \\
& CA Geometry outliers & 3 & $1.40 \%$ & Goal: $<0.5 \%$ \\
\hline
\end{tabular}

In the column results, the left column gives the raw count, right column gives the percentage.

${ }^{*} 100^{\text {th }}$ percentile is the best among structures if comparable resolution; $0^{\text {th }}$ percentile is the worst.

${ }^{*}$ MolProbity score combines the clashscore, rotamer, and Ramachandran evaluations into a single score, normalized to be on the same scale as $\mathrm{X}$-ray resolution.

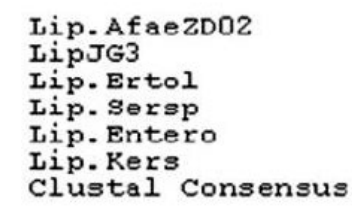

Lip.AfaezDO2
LipJG3
Lip. Ertol
Lip. Sersp
Lip. Entero
Lip. Kers
Clustal Consensus

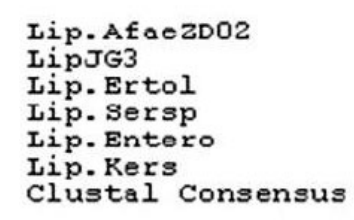

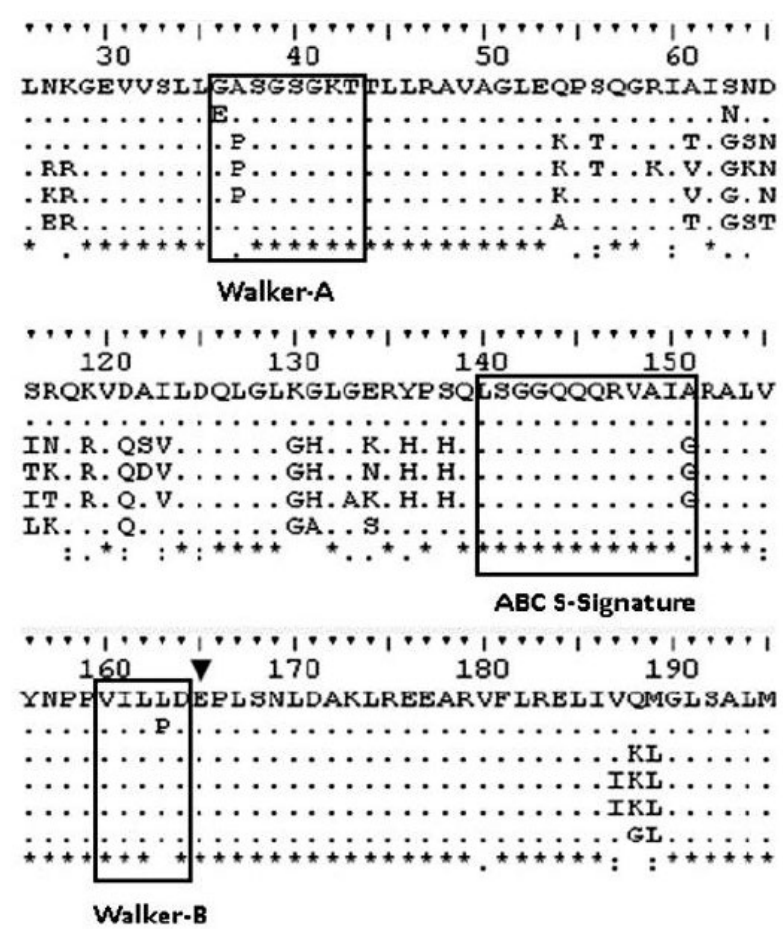

Fig 6. Partial sequence alignment of the amino acid sequence of LipJG3 against lipases from Alcaligenes faecalis (WP_060185877.1), Erwinia toletana (WP_017803199.1), Serratia sp. (WP_017893896.1), Enterobacteriaceae (WP_032660170.1), and Kerstersia gyiorum (WP_068375151.1). Stars $\left(^{*}\right)$ indicate amino acid identity across all sequences. Black boxes represents ATP- and GTP-binding site Walker-A and Walker-B motifs as well as ABC transporter family signature. The position of the putative catalytic base is displayed by black triangle above the sequences 
found in previous works, lipases from Serratia marcescens [27] and Pseudomonas fluorescens [30].

At least, there are two possible reasons underlined the classification of LipJG3. First, LipJG3 was involved in modification of nucleic acid, which are analogous to $A B C$ transporters proteins. Consequently, this nontransporters $\mathrm{ABC}$ proteins have an ATP-binding fold and spatial conserved residues that might be important for ATPase activity. The second reason is its possibility secreted by $A B C$ exporter pathway thus it brings the small unit characters of $\mathrm{ABC}$ transporter protein [31]. Additionally, the production of extracellular lipase from $\mathrm{ABC}$ pathway is more efficient than general secretion pathway [32].

One specific characteristic of any enzyme is its signature catalytic site used for the binding of a specific substrate. Generally, a lipase that belongs to the true lipase family has catalytic triad signature residues: a nucleophilic residue (cysteine, serine, or aspartate), a catalytic acid residue (aspartate or glutamate), and a histidine [33]. Since LipJG3 does not belong to the true lipase family, it is difficult to ascertain the catalytic triad, Ser $(\mathrm{S})$, His $(\mathrm{H})$, and Asp (D). Thus, it is also challenging to explain its role as a hydrolase enzyme. In the case of the $\mathrm{ABC}$ transporter protein itself, a previous study [34] proposed that a conserved glutamic acid residue (E) located next to the aspartic acid residue (D) of the Walker-B motif (Fig. 6) is directly responsible for the hydrolytic activity of the $\beta-\gamma$ phospodiester bond. On the other hand, there are two $\mathrm{Mg}^{2+}$ ions (Fig. 5(b)) networking with the conserved region in the $3 \mathrm{D}$ model. One ion interacts with the catalytic triad of $\mathrm{T}^{20}, \mathrm{D}^{143}$, and $\mathrm{V}^{173}$ residues, while another interacts with the $\mathrm{G}^{199}, \mathrm{~S}^{200}$, and $\mathrm{E}^{203}$ residues. $\mathrm{Mg}^{2+}$ ion was recognized as the cofactor enzyme for hydrolyzing ATP in $\mathrm{ABC}$ transport protein [35-36]. Thus, it might be possible for the two catalytic triads involved in hydrolyzing reactions of LipJG3. However, there are no reports explaining in detail about the catalytic site residues of lipases that belong to the $\mathrm{ABC}$ transport protein. In spite of this, gene expression and enhanced secretion of several lipases from this group have been reported [27,30,32]. Taking into consideration all of the evidence, LipJG3 could be used to hydrolyze triacylglycerides as these are the natural substrates of the enzyme, and convert them into biodiesel.

\section{- CONCLUSION}

The novel bacterial lipase from Alcaligenes sp. JG3 (LipJG3) was characterized. It shared a $98 \%$ similarity in amino acid sequence level towards a lipase from $A$. faecalis. Due to its possibility to be secreted by the ABC pathway, LipJG3 brings the same nucleotide binding domains of ATPase. Thus, our results suggest that LipJG3 and its homolog proteins belong to the $\mathrm{ABC}$ transporter protein superfamily.

\section{- ACKNOWLEDGMENTS}

This manuscript was a result of a self-funded study. Norman Yoshi Haryono and Peni Lestarini are acknowledged for sharing the bacterial culture and for helping with the DNA Sequencing process.

\section{- REFERENCES}

[1] Gupta, R., Gupta, N., and Rathi, P., 2004, Bacterial lipases: An overview of production, purification and biochemical properties, Appl. Microbiol. Biotechnol., 64 (6), 763-781.

[2] Salihu, A., and Alam, Z., 2015, Solvent tolerant lipases: A review, Process Biochem., 50 (1), 86-96.

[3] Angajala, G., Pavan, P., and Subashini, R., 2016, Biocatalysis and agricultural biotechnology lipases: An overview of its current challenges and prospectives in the revolution of biocatalysis, Biocatal. Agric. Biotechnol., 7 (C), 257-270.

[4] Fischer, M., and Pleiss, J., 2003, The lipase engineering database: A navigation and analysis tool for protein families, Nucleic Acids Res., 31 (1), 319-321.

[5] Jaeger, K.E., Dijkstra, B.W., and Reetz, M.T., 1999, Bacterial biocatalysts: Molecular biology, threedimensional structures, and biotechnological applications of lipases, Annu. Rev. Microbiol., 53, 315-351.

[6] Hasan, F., Shah, A.A., and Hameed, A., 2006, Industrial applications of microbial lipases, Enzyme Microb. Technol., 39 (2), 235-251. 
[7] Aravindan, R., Anbumathi, P., and Viruthagiri, T., 2007, Lipase applications in food industry, Indian J. Biotechnol., 6 (2), 141-158.

[8] Nurosid, Oedjijono, and Lestari, P., 2008, Kemampuan Azospirillum sp. JG3 dalam menghasilkan lipase pada medium campuran dedak dengan waktu inkubasi berbeda, Molekul, 3, 1-12.

[9] Raharjo, T.J., Haryono, N.Y., Nataningtyas, D.R., Alfiraza, E.N., and Pranowo, D., 2016, Characterization of lipase gene fragment from Alcaligenes sp. JG3 bacterium, Am. J. Biochem. Mol. Biol., 6 (2), 45-52.

[10] Kaur, G., Singh, A., Sharma, R., Sharma, V., Verma, S., and Sharma, P.K., 2016, Cloning, expression, purification and characterization of lipase from Bacillus licheniformis, isolated from hot spring of Himachal Pradesh, 3 Biotech, 6 (1), 49.

[11] Kumar, S., Stecher, G., and Tamura, K., 2016, MEGA7: Molecular Evolutionary Genetics Analysis Version 7.0 for bigger datasets, Mol. Biol. Evol., 33 (7), 1870-1874.

[12] Nataningtyas, D.R., 2017, Molecular characterization of lipase gene from Alcaligenes sp. JG3 bacterium, Thesis, Universitas Gadjah Mada, Yogyakarta, Indonesia.

[13] Biasini, M., Bienert, S., Waterhouse, A., Arnold, K., Studer, G., Schmidt, T., Kiefer, F., Cassarino, T.G., Bertoni, M., Bordoli, L., and Schwede, T., 2014, SWISS-MODEL: Modelling protein tertiary and quaternary structure using evolutionary information, Nucleic Acids Res., 42, 252-258.

[14] Kelley, L.A., Mezulis, S., Yates, C.M., Wass, M.N., and Sternberg, M.J., 2015, The Phyre2 web portal for protein modeling, prediction and analysis, Nat. Protoc., 10 (6), 845-858.

[15] Chen, V.B., Arendall, W.B., Headd, J.J., Keedy, D.A., Immormino, R.M., Kapral, G.J., Murray, L.W., Richardson, J.S., and Richardson, D.C., 2010, MolProbity: All-atom structure validation for macromolecular crystallography, Acta Crystallogr., Sect. D: Biol. Crystallogr., 66 (Pt 1), 12-21.

[16] Pettersen, E.F., Goddard, T.D., Huang, C.C., Couch, G.S., Greenblatt, D.M., Meng, E.C., and Ferrin, T.E., 2004, UCSF Chimera-a visualization system for exploratory research and analysis, J. Comput. Chem., 25 (13), 1605-1612.

[17] Lestari, P., Handayani, S.N., and Oedjijono, 2009, Sifat-sifat biokimiawi ekstrak kasar lipase ekstraseluler dari bakteri Azospirillum sp. JG3, Molekul, 4, 73-82.

[18] Vashishth, A., and Tehri, N., 2015, The role of recombinant DNA technology for human welfare, Int. J. Res. Biol. Sci., 5 (4), 35-39.

[19] Ethica, S.N., 2014, Detection of genes involved in glycerol metabolism of Alcaligenes sp. JG3, Dissertation, Universitas Gadjah Mada, Yogyakarta, Indonesia.

[20] Drancourt, M., and Raoult, D., 2005, Sequencebased identification of new Bacteria: A proposition for creation of an orphan bacterium repository, $J$. Clin. Microbiol., 43 (9), 4311-4315.

[21] Kim, M., Oh, H., Park, S., and Chun, J., 2014, Towards a taxonomic coherence between average nucleotide identity and 16S rRNA gene sequence similarity for species demarcation of prokaryotes, Int. J. Syst. Evol. Microbiol., 64 (Pt 2), 346-351.

[22] Bell, P.J., Sunna, A., Gibbs, M.D., Curach, N.C., Nevalainen, H., and Bergquist, P.L., 2002, Prospecting for novel lipase genes using PCR, Microbiology, 148 (Pt 8), 2283-2291.

[23] Voget, S., Leggewie, C., Uesbeck, A., Raasch, C., Jaeger, K., and Streit, W.R., 2003, Prospecting for novel biocatalysts in a soil metagenome, Appl. Environ. Microbiol., 69 (10), 6235-6242.

[24] Wong, H., and Schotz, M.C., 2002, The lipase gene family, J. Lipid Res., 43 (7), 993-999.

[25] Berezin, C., Glaser, F., Rosenberg, J., Paz, I., Pupko, T., Fariselli, P., Casadio, R., and Ben-Tal, N., 2004, ConSeq: The identification of functionally and structurally important residues in protein sequences, Bioinformatics, 20 (8), 1322-1324.

[26] Cygler, M., Schrag, J.D., Sussman, J.L., Harel, M., Silman, I., Gentry, M.K., and Doctor, B.P., 1993, Relationship between sequence conservation and three-dimensional structure in a large family of esterases, lipases, and related proteins, Protein Sci., 2 (3), 366-382. 
[27] Li, X., Tetling, S., Winkler, U.K., Jaeger, K., and Benedik, M.J., 1995, Gene cloning, sequence analysis, purification, and secretion by Escherichia coli of an extracellular lipase from Serratia marcescens, Appl. Microbiol. Biotechnol., 61 (7), 2674-2680.

[28] Park, Y., Moon, Y., Ryoo, J., Kim, N., Cho, H., and Ahn, J.H., 2012, Identification of the minimal region in lipase $\mathrm{ABC}$ transporter recognition domain of Pseudomonas fluorescens for secretion and fluorescence of green fluorescent protein, Microb. Cell Fact., 11, 60.

[29] Orelle, C., Dalmas, O., Gros, P., Di Pietro, A., and Jault, J.M., 2003, The conserved glutamate residue adjacent to the Walker-B motif is the catalytic base for ATP hydrolysis in the ATP-binding cassette transporter BmrA, J. Biol. Chem., 278 (47), 4700247008.

[30] Ahn, J.H., Pan, J.G., and Rhee, J.S., 1999, Identification of the tliDEF ABC transporter specific for lipase in Pseudomonas fluorescens SIK W1, J. Bacteriol., 181 (6), 1847-1852.

[31] Binet, R., Létoffé, S., Ghigo, J.M., and Delepelaire, P., and Wandersman, C., 1997, Protein secretion by
Gram-negative bacterial ABC exporters - A review, Gene, 192 (1), 7-11.

[32] Ahn, J.H., Pan, J.G., and Rhee, J.S., 2001, Homologous expression of the lipase and $A B C$ transporter gene cluster, tliDEFA, enhances lipase secretion in Pseudomonas spp., Appl. Environ. Microbiol., 67 (12), 5506-5511.

[33] Arpigny, J.L., and Jaeger, K.E., 1999, Bacterial lipolytic enzymes: Classification and properties, Biochem. J., 343 (Pt 1), 177-183.

[34] Muneyuki, E., Noji, H., Amano, T., Masaike, T., and Yoshida, M., 2000, $\mathrm{F}_{0} \mathrm{~F}_{1}$-ATP synthase: General structural features of 'ATP-engine' and a problem on free energy transduction, Biochim. Biophys. Acta, 1458, 467-481.

[35] Yuan, Y., Blecker, S., Martsinkevich, O., Millen, L., Thomas, P.J., and Hunt, J.F., 2001, The crystal structure of the MJ0796 ATP-binding cassette, implications for the structural consequences of ATP hydrolysis in the active site of an the ATPbound form of the HisP ATP-binding cassette, $J$. Biol. Chem., 276 (34), 32313-32321.

[36] Wilkens, S., 2015, Structure and mechanism of ABC transporters, F1000Prime Rep., 7, 14. 